\title{
Improved Engineering Tribological Property of Natural Fibres by Surface Modifications: A Review
}

\author{
Obuka Nnaemeka S. P*, Ani Ndubuisi J, Ozioko Emeka R
}

Department of Mechanical/Production Engineering, Enugu State University of Science and Technology, Enugu, Enugu State, Nigeria

DOI: $10.36348 /$ SIJCMS.2019.v02i06.001

| Received: 05.09.2019 | Accepted: 16.09.2019| Published: 14.10.2019

*Corresponding author: Dr. Obuka Nnaemeka S. P

\section{Abstract}

Increasing interest in natural fibres for composite material formation and applications informs the aim of this paper on review of various surface modification methods employed towards the improvement of the Tribological properties of these fibres for interfacial bonding with polymer matrices. Natural fibres have wonderful properties ranging from accessibility, bi-degradability, recyclability, low density and many more but have particular negative characteristic that needs to be corrected in order to improve its surface interaction with composite matrices; which is their great affinity for water. Different methods of treating natural fibres have been applied towards reducing the hydrophilic nature of these fibres. These surface modification processes do not only reduce water absorption capability of these fibres but also increases fibrillation and material wettability. This review of literatures showed that mercerization treatment and acetylation treatment are the most applicable surface modifications or treatments for natural fibres.

Keywords: Natural Fibre, Tribology, Surface Modification, Composites, Mercerization, Acetylation.

Copyright @ 2019: This is an open-access article distributed under the terms of the Creative Commons Attribution license which permits unrestricted use, distribution, and reproduction in any medium for non-commercial use (NonCommercial, or CC-BY-NC) provided the original author and source are credited.

\section{INTRODUCTION}

Whenever natural fiber is mentioned these words inevitably follow; environment, green, biodegradability, renewability, availability, recyclability, inexpensive, low-density and so on. In the area of engineering, scientific and material research, composites have become a household research interest because of their wide applicability, cost effectiveness, high strength to weight ratio, and other positive properties.

In polymer matrix composites, fibrous materials that are either synthetic or natural are added as fillers or as reinforcements that provide strength and stiffness to the structure, while the polymer acts as the load transferring medium and serves as the adhesive holding the fibres in place [1]. Based on the promise of "the whole is better than the sum of its parts", the material is created with properties that are better than those of the its individual components [2]. Major improvement in area of polymer (plastic) composites came towards the end of the first half of the $20^{\text {th }}$ century when glass fibres were used to reinforce thermoplastics and thermosets. Then other synthetic fibres followed such as; carbon, ceramics (alumina) and aramids [3]. These synthetic materials in the form of fibres are preferred not only for their high strength but also for their high surface-to-volume ratio, which provides much area of contact between matrix and the reinforcement for a more efficient load transfer. They have advantages over conventional materials (metal alloys) in areas of ease of formability, very low density compared to metals, excellent surface finish, high strength-to-weight ratio, very high corrosion resistance, etc [4]. These materials like glass fibre reinforced polymers have disadvantages such as; non-renewability, high abrasiveness (wear of processing equipment) health hazards, environmental pollution (nondegradable), expensive etc.

Plastic wastes in recent years have become environmentally unfriendly because of difficulties in disposing them after end use life. Increased environmental awareness, recent technological innovation, new industrial applications, new policies and legislations are compelling industries to discover and employ new materials that are more eco-friendly [5]. However, due to the need for more environmentally friendly materials, Natural Fibre Composites (NFC) are gaining the attention that once has been shifted to synthetic products. The first known utilization of NFC was straw reinforced day for bricks and pottery reported by Barbero [6]. 
Natural fibre composites have been found to possess good mechanical properties with low specific mass, better electrical resistance, good thermal and acoustic insulating properties. Nevertheless, natural fibre reinforced polymer matrix composites suffer from lower modulus, lower strength and relatively poor moisture resistance compared to synthetic fibre composites [7]. Natural fibres are generally lingocellulosic in nature, consisting of helically wound cellulose micro fibrils in a matrix of lignin and hemicellulose [8]. Invariably, understanding of NFCs physical properties such as mechanical and thermal behaviours will enable engineers to produce optimum design for any structure as was stated in works of Marsh [9]; Kim, Lee, Kang and Kang [10]; Agarwal, Saxena, Sharma, Thomas and Pothan [11]; Springer and Tsai [12].

The underlying principle in fibre composites is to utilize fibres as reinforcement in matrix of resin. The fibres usually provide the greatest share of strength while resin provides binding to the fibers. Ticoalu, Aravinthan, and Cardona [13] state that fibres themselves cannot be used to sustain actual loads, hence, resin is used to bind and protect the fibres. The properties of fibre composites can be tailored to achieve the desired end product depending on the type of fibres, type of resin, the proportion of fibre-resin and the type manufacturing process $[14,15]$.

Growing environmental concern and awareness due to impact of human activities such as, increased pollution, increasing demand for biodegradable materials, material need for $\mathrm{CO}_{2}$ neutrality and low greenhouse gas emissions, new environmental laws scientists are much interested in studying novel environmental friendly materials $[16,2$, 17]. Since last decade, intensive researcher and developments have been carried out in order to develop powerful composites using natural fibres, offering good bio-degradability, and sustainability. Zhu et al., [17]; Cheung, HO, Lau, Cardona and Hui [18] in their works placed that a biodegradable material will slowly undergo and exposure to the elements and hence could provide solutions to end-to-life issues after service life. Emphatically, natural fibre reinforced composites show supremacy over conventional materials owing to ease of processing, fast production cycling and low tooling cost, thus making them most suitable materials for applications like automobile and electrical industries. The main attraction of these composites lies in the possibility of achieving very short demoulding times as no chemical reaction is required.

Natural fibre composite is actually not a new technology found in human history. Egyptians should have been given the credit on introducing natural fibre composite to human civilization since the greatest known composite was found in Egypt. The pyramid of Egypt was built using a combination of straw, clay and sand [19]. Based on this evidence, now researchers are pursing to develop a natural fibre composite that can give comparable strength with existing materials such as wood, steel, plastic and also synthetic fibre composites. Traditionally, natural fibre composites have been in use in production of many household components/products like, basket, clothing, sacks, ropes, rug, kitchen cabinet, tray etc [20]. Natural fibre reinforced polymer composites have raised great interests among material scientists and engineers in recent years due to the consideration of developing an environment friendly material, and partly reducing the dependency on glass fibre [21]. Also according to Leman, Sapuan, Saifol, Maleque and Ahmad [22, 23] new environmental regulations and uncertainties about petroleum and timber resources have triggered much interest in developing composite materials from natural fibres. Moreover, economic and other related factors in many developing countries where natural fibres are abundant, demand that scientists and engineers apply appropriate technology to utilize these natural fibres as effectively and economically as possible to produce good quality fibre reinforced polymer composites for housing and other needs as stated by Joseph and Sabu [24].

According to Shehu, Audu, Nwamara, AdeAjayi, Shittu and Isa [25], natural fibres are elongated substances produced by plants and animals that can be spun into filaments thread or rope, woven, knitted, mattered or bonded, they form fabrics that are useful to the society. Flax, hemp, jute, straw, wood fibre, rice husks, wheat, barley, oats, cane (sugar and bamboo), grass reeds, kenaf, ramie, oil palm empty fruit bunch, sisal, coir, water hyacinth, pennyworth, Kapok, paper mulberry, raphia, banana fibre, pineapple leaf fibre, abaca, areca and so on are various types of natural fibres that can be used in plastic composites [26]. Natural fibre composites can be a combination of either natural fibres/synthetic resin or natural fibres/bio-resin. Bio-resins means bio-degradable resin. Both synthetic and bio-resin can be either in the form of thermoset or thermoplastic type of resin. Natural fibres/thermoplastic composites have been used extensively in automobile application [27]. While most composites for infrastructure are made out of thermoset resins [28] natural fibre composites or bio-composites have been used also in biomedical applications for bone and tissues repair and reconstruction [18].

\section{Classifications of Natural Fibres}

Natural fibre composites (biocomposites) are primarily composed of a combination of cellulose, hemicelluloses, pectin and lignin, which are derived not only from leaf (e.g. Sisal) bast (e.g. flax and hemp) sealed (e.g. cotton) and fruit (e.g. coir), but also from other sources such as chicken feather [27, 29]. Plant fibres are composed of cellulose while animal fibres consist of protein (hair, silk and wool), there are also mineral fibres (e.g. Asbestos) as stated by Subramani 
and Vishnupriya [30]. There are thousands of natural fibre available and therefore there are many research interests in utilization of natural fibres to improve the properties of composites. Fig-1 shows the classification of natural fibres [25].

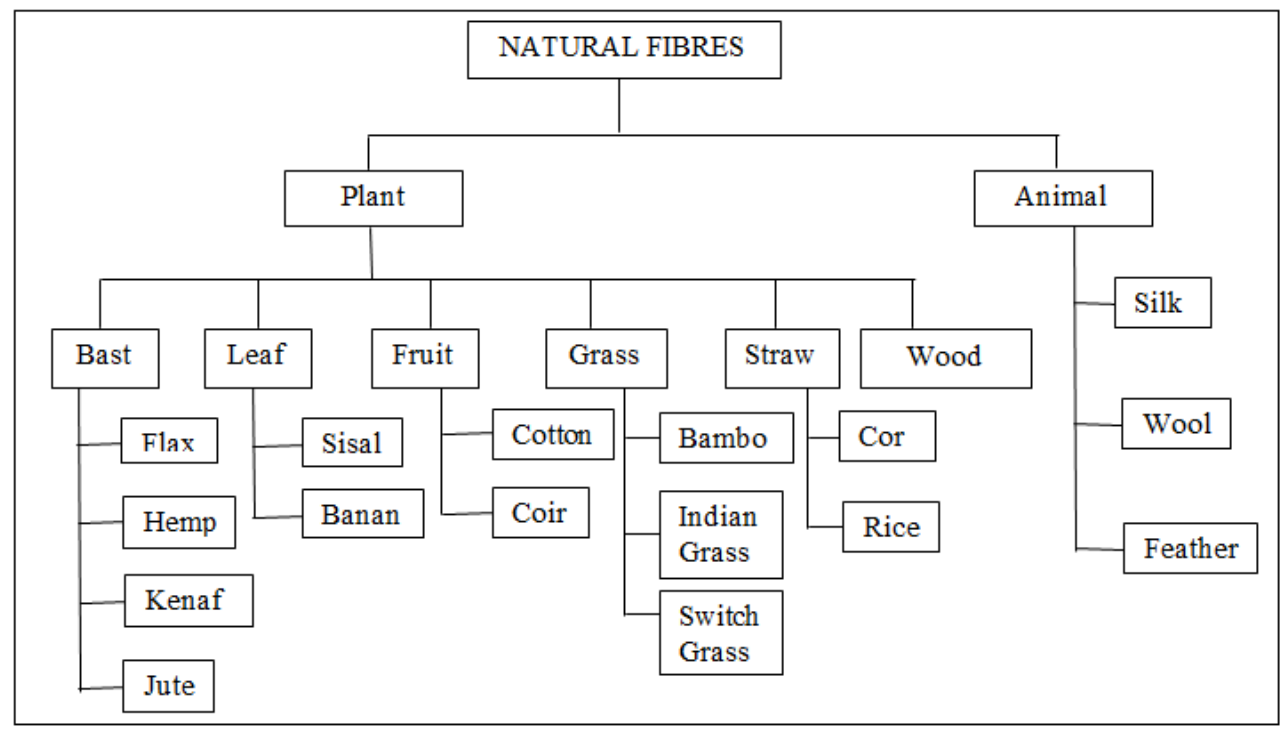

Fig-1: Classification of Natural Fibres [25]

As depicted by Fig-1, natural fibres are classified according to their origin as also stated by Gunti and Atluri [31] as follows;

(a) Animal fibres: contains wool, silk, avian fibre. They include sheep wool, goat hair, horse hair, feathers and feathers fibre etc.

(b) Mineral fibres: Are naturally occurring fibre or slightly modified fibre produced from minerals. These can be further categorized as asbestos, ceramic and metal fibres.

(c) Plant fiber: Are generally comprised mainly of cellulose. These fibres can be further categorized into

- $\quad$ Seed fibre: Fibre collected from the seed and seed case e.g. cotton and kapok

- Leaf fibre: fibres collected from leaves e.g. sisal, agave, maize.

- $\quad$ Skin fibre: fibres collect from the skin or bast surrounding the stem of their respective plant these fibres have higher tensile strength than other fibres. Hence, they are used for durable yam, fabric, packaging, and paper. Examples are jute, flax, banana, hemp and soybean.

- $\quad$ Fruit fibre: fibre are collected from the fruit of the plant e.g. coconut (coir) fibre.

- $\quad$ Stalk fibre: fibre are actually the stalks of the plants such as; straws of wheat, rice, barley and other crops including bamboo, grass and wood.

\section{Properties of Natural Fibres}

Physical and mechanical properties of biocomposites depend on the single fibre chemical composition (cellulose, hemicelluloses, lignin, pectin, waxes, water content, and others) according to grooving (soil feathers, climates, aging condition) and extraction/processing method conditions. Bongarde and Shinde [32] have it that growing conditions are recognized as the most influencing parameter for the variability of mechanical properties of the fibres.

\section{Chemical Properties/Compositions of Natural Fibres}

Sequel to the previous section, Alamri and Low [33] stated that, natural fibres (except cotton) are generally composed of cellulose, hemicelluloses, lignin, aches and some water-soluble compounds. They generally contain $60-80 \%$ of cellulose, $5-20 \%$ lignin and up to $20 \%$ moisture. Cellulose is considered the major framework component of the fibre structure. It provides strength, stiffness and structural stability of the fibre. Hemicelluloses occur mainly in the primary cell wall and has branched polymers containing five and six carbon sugars (Fig-2) of varied chemical structures. Lignin is amorphous and has an aromatic structure (Fig3 ). Pectin comprises of complex polysaccharides. Their side chains are cross-linked with the calcium ion and arabinose sugars. As the processing temperature increases, the surface of cell wall of natural fibres will experience pyrolysis. Pyrolysis process is a chemical decomposition of organic material at high temperature in the absence of oxygen [34]. 


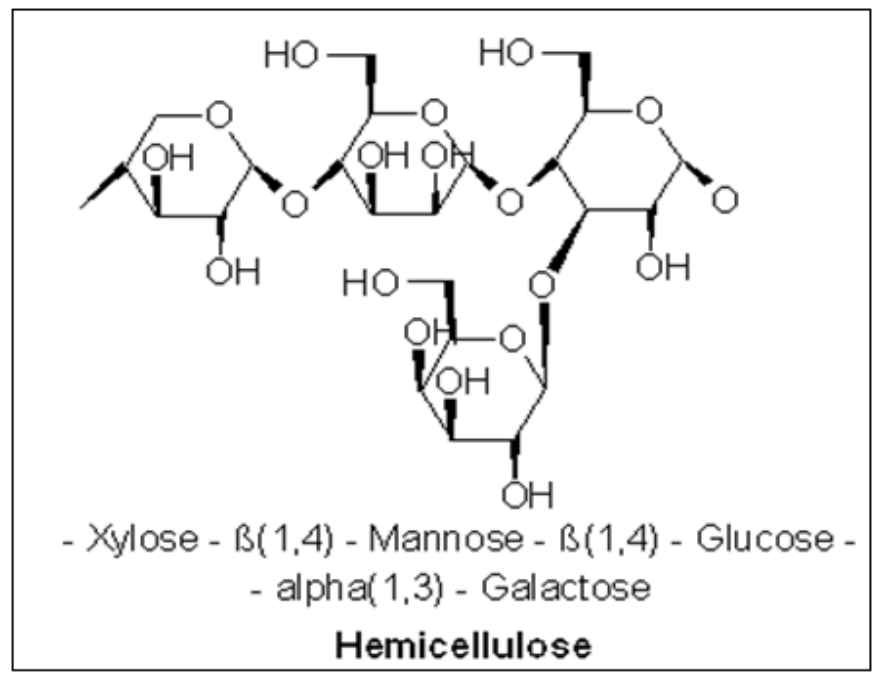

Fig-2: Structure of Hemicelluloses

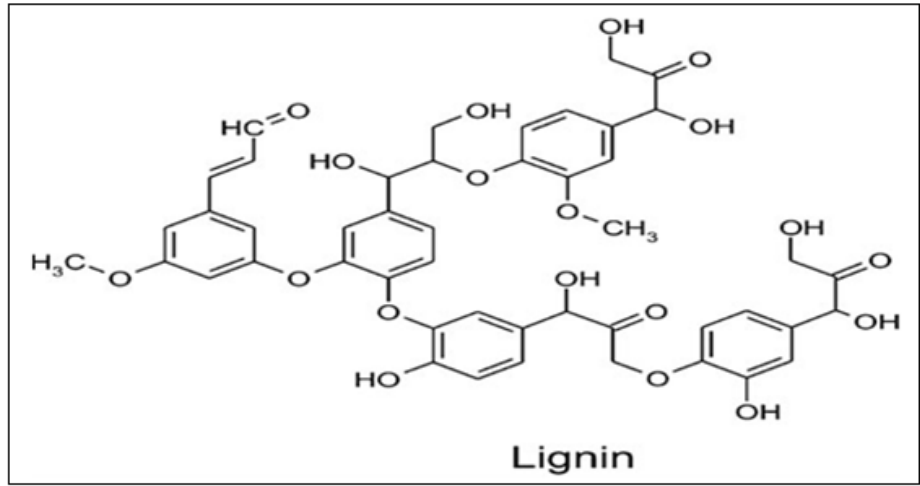

Fig-3: Structure of Lignin

\section{Surface Modification /Treatments of Natural Fibres}

A major disadvantage associated with the use of natural fibres as reinforcements in composites is their high hydrophilic nature which leads to low mechanical properties and sometimes delamination. This reduction in mechanical properties cannot be unconnected to poor interfacial (topological property) bonding the hydrophobic (inorganic) matrices and the hydrophilic (organic) natural fibres. Therefore, to enhance the effective interfacial bonding between fibre and matrix, the fibre surface needs to be chemically modified [3537]. Also to surmount the problem of surface treatment, compatible agents need to be applied prior to composite formation. These treatments both chemical and biological, help in improving the mechanical properties of the fibres by making them more hydrophobic [38, 39]. According to Knoshnava, Rostami, Ismai and Valipour [40] surface modification of natural fibres is not only through chemical or biological treatment but also through other treatments that are termed "Physical Method", which they reviewed from the work of Netravali [41].

\section{Biological Treatment}

Biological treatment of natural fibres has been recently considered as a promising alternative for surface modification of fibres. This treatment is environmentally friendly and efficient. Biological treatment is used to remove non-cellulosic components (such as wax) from the fibre surface by the action of specific enzymes [25]. There are two main novel type of biological treatments in literature today. They are; (i) Fungi treatment and (ii) Bacterial treatment.

\section{Fungi Treatment}

Fungi treatment causes the formation of holes (pits) on fibre surfaces which provide roughness adhesion between fibre and matrix [42, 43]. White rot fungi have the ability to selectively degrade lignin at a faster rate than cellulose and produce extra cellular oxidases [44, 45]. Obviously, this enzyme action enables these fungi to degrade not only lignin, but also an extensive range of other non-lignin related aromatic and non-aromatic compounds. The most important lignin degrading enzymes are Lignin Peroxidases (Lip), Manganese Peroxidases (MnP) and Lacases [46, 47].

In addition, fungi produce an extensive system of hyphae, which roughens the surface of the natural fibres. White not fungi are aerobic microorganisms and need the presence of sufficient oxygen to grow [48, 49] and able to use organic molecules which dissolve in 
water indicates the optimum conditions for white rot fungi growth [50-52].

According to Gulati and Sani [53], fungimodification is novel method for improving adhesion characteristics of natural fibres developed. In their research, Hemp was the natural fibre and Ophiostoma Ulmi as the fungi and it was discovered that fungi over alkali treatment shoed a $32 \%$ improvement in composite strength. The Scanning Electron Microscopy (SEM) of hemp fibres after treatment showed treated fibres are relatively free of impurities that could be due to removal of water soluble (hemicelluloses) compounds and action of fungus on the hemp fibre.

\section{Bacterial Treatment}

Bacterial on microbial cellulose is produced by certain bacteria belonging to the genera Acetobacter, Agrobacterium, Alealigenes, Pseudomonas, Rhizobium or Sarcina, the most efficient producer of bacterial cellulose being Acetobacter xylinum [54]. Acetobacter xylinum, an obligate aerobe, produces extracellular cellulose microfibrils to provide for a firm matrix that floats and therefore, allows the embedded bacteria to stay in close contact with atmosphere [55]. Recently, Guhados, Wan and Hutter [56], measured the elastic modulus of single bacterial cellulose fibril using atomic force microscopy to be $78 \mathrm{GPa}$, which is much higher than those of natural fibres (generally less than $30 \mathrm{GPa}$ ) and is in the same order as that of glass fibres (70GPa). This makes bacterial cellulose a very promising green nano-reinforcement [27, 57].

Inspired by nature, creating very complex hierarchical structures by assembly of molecules of different sizes where high mechanical resistance is needed, such as in plant cell, walls, animal shells, and bones, Pommet et al., [55] proposed an alternative way of modifying natural fibre surface. They put forward a way to modify the surface of natural fibres by utilizing bacteria (Acetobacter Xylinum) to deposit nanosized bacterial cellulose around natural fibres, which enhances their adhesion to renewable polymers. They discovered that the persistence of the modification after $\mathrm{NaOH}$ extraction shows the strength by which bacterial cellulose is attached to the natural filler. The adhesion between the deposited cellulose and the natural fibres can be enhanced by pretreating the fibres by a solvent extraction to remove hydrophilic compounds from the filler surface.

\section{Physical Treatment}

Physical treatments change the structural and surface properties of natural fibre with the main advantage that is enhanced mechanical bonding between natural fibres and the matrix without altering the chemical composition of the fibre. One of the most interesting techniques of physical treatment is the Corona treatment $[58,59]$. This technique has provided various advantages such as improved mechanical properties and the composites properties with enhancement around $30 \%$ of Young modulus, increased tensile strength, and also exhibited significant, higher polar components of free surface energy with increasing treatment energy output [60].

Plasma treatment is another physical treatment method that has provided advantages like; improved fibre matrix adhesion and enhanced mechanical property, stiffness, enhance interfacial adhesion, resulted in the development of hydrophobicity in fibres and improved tensile and flexural strength [61-64]. Plasma is an ionized gas containing negative, positive and neutral particles. When a sample is exposed to a plasma gas, energetic charged particles inside the plasma are able to interact chemically with the surface of the sample [65]. Plasma surface modification affects the wettability, dyeability, and adhesion of materials. In general, plasma surface treatment does not change or break the bulk materials, it does not remove or deposit more than a few layers to the surface of materials, and it does not remove bulk materials [66]. The effect of plasma treatment on materials might be categorized into two, types of surface and structure changes (bulk modification).

\section{Chemical Treatment}

There are different type of chemical treatment or surface modifications on natural fibres they are; alkaline (Mercerization) Sikine, benzoylation, stearic acid, fatty acid derivative (Oleoyle Chloride) and triazine. Shehu et al., [25] have it that, the major problems of natural fibre composites originate from the hydrophilic nature of the fibre and the hydrophobic nature of the matrix. The inherent incompatibility between these two phases results in weakened bonding at the interface. However, chemical treatment on reinforcing fibres can reduce their hydrophilic tendency and thus improve compatibility with the matrix. The following review has been drawn from several research activities that were conducted towards the improvement of fibre adhesion properties with matrix through chemical treatments.

\section{Alkaline (Mercerization) Treatment}

Alkaline treatment or mercerization is one of the best used chemical treatment for natural fibres. Sodium hydroxide $(\mathrm{NaOH})$ or alkaline changes the orientation of highly packed crystalline cellulose order and forming an amorphous region where cellulose micro molecules are separated at large distance and spaces are filled by water molecules [67]. Mercerization leads to fibrillation which causes the breaking down of the composite fibre bundle into smaller fibres. It reduces fibre diameter, thereby increasing the aspect ratio which leads to the development of a rough surface topography that results in better fibre/matrix interface adhesion and certainly an increase in mechanical properties [1, 68-70]. According to Fengel and Wegener [71], the type of alkaline treatment such as $\mathrm{KOH}$, 
$\mathrm{LiOH}, \mathrm{NaoH}$ and its concentration will influence the degree of swelling and degree of lattice transformation into cellulose.

Alkali sensitive hydroxyl $(\mathrm{OH})$ groups present among the molecules are broken down and they then react with water molecules $(\mathrm{H}-\mathrm{OH}$ and move out form the fibre structure. The remaining reactive molecules form fibre cell-O-Na groups between the cellulose molecular chains. Through this, hydrophilic hydroxyl groups are reduced and hence make the fibres to exhibit hydrophobic property. It also eliminates certain portions of hemicelluloses, lignin, pectin, wax and oil covering materials [72]. These make the fibre surface to become more homogenous due to the elimination of microvoids and the stress transfer capacity between the ultimate cells improves. This increases effective fibre surface area for good adhesion with the matrix equation (2.1) depicts the chemical reaction between the fibre cell and alkaline, thus;

$$
\text { Fibre }-\mathrm{OH}+\mathrm{NaOH} \rightarrow \text { Fibre }-\mathrm{O}^{-} \mathrm{Na}^{+}+\mathrm{H}_{2} \mathrm{O}
$$

Baranitharan and Mahesh [117] reported the result of alkali treated maize fibres reinforced Epoxy poly matrix composite. They found out that alkali treated maize fibres water holding capacity was more than two times greater than raw fibres. Jacob, Thomas and Varughese [73] worked on the effect of $\mathrm{NaOH}$ concentrations $(0.5,1,2,4$ and 10\%) for treating sisal fibre reinforced composites and concluded that maximum tensile strength resulted from $4 \% \mathrm{NaOH}$ treatment at room temperature. In the same vein, 5\% $\mathrm{NaOH}$ treated fibre reinforced polyester composites having better tensile strength than $10 \% \mathrm{NaOH}$ treated composited was observed by Mishra, Mohanty, Drzal, Misra, Parija, Nayak and Tipathy [39].

Mercerization is one of the treatments and fibre modification technique that will be adopted in this research, so we deem it necessary to further review its applications in the area of natural fibre and polymer matrix adhesion. Furthermore, mercerization increases the number of possible reactive sites, allows better fibre wetting and gets an effect on the chemical composites of the fibres, Alkali treatment is recognized to hydrolyze the amorphous parts of cellulose present in fibres so that after treatment the material contains more crystalline cellulose [74] and it also removes waxes and oil from the fibre surface [75]. Mercerization also takes out certain portion of hemicelluloses, lignin, pectin, wax and oil covering the fibres, as a result, the fibre surface becomes more uniform due to the elimination of microvoids and thus stress transfer capacity between the ultimate cells improves [76-79].

Laly, Jayamol, and Sabu [80] studied the effect of surface treatments on the fibre-matrix interaction in banana fibre reinforced polyester composites. The found that $1 \% \mathrm{NaOH}$ concentration produced a composite of $70 \mathrm{MPa}$ tensile strength, while $0.5 \%$ alkali concentration treated composite yielded $65 \mathrm{MPa}$ of strength and untreated gave 58MPa tensile strength, hence, an improved property due to mercerization. Ramadevi, Sampathkumar, Srinivassa and Bennehalli [81] investigated the effect of alkali treatment on water absorption of single cellulosic abaca fibre. They reported that the abaca fibre treated with $20 \% \mathrm{NaOH}$ showed about 38.27, 52.94, 62.50, and 63.50 percent lower moisture absorption properties than the untreated abaca fibre. Therefore, alkali treatment has improved the hydrophobic property of the abaca fibre.

Mokaloba and Batane [82], studied the effects of mercerization and acetylation treatments on the properties of sisal fibre and its interfacial characteristics on polypropylene. They tested five samples of the sisal fibres, where the untreated samples had average tensile strength values of $482 \mathrm{MPa}$, against $561 \mathrm{MPa}$ and $548 \mathrm{MPa}$ for acetylated and mercerized fibres respectively. Favaro, Ganzerli, De Carvalho Neto, Da Silva, and Radovanovic [83] investigated the effects of mercerization and acetylation on sisal fibre compatibility with oxidized high density polyethylene (HDPE), reporting an improved fibre-matrix adhesion. A structural transformation of fibres from cellulose I to cellulose II upon mercerization was reported by Ouajai, Hodzic, and Shanks [84]. In the same token, Jayaramudu, Guduri, and Rajulu [85] also reported changes to the cellulose structure and index of crystallinity on mercerized sterculia urens fabric.

There are so many more research that were carried out to investigate the action of alkali treatment on natural fibre to mention but a few, stressing the importance of natural fibres modification through mercerization. Table-1 shows the summary of other research works conducted in this area but not all that could be found in literature. 
Table-1: Compiled Mercerization Treatment Parameters from Literature [86]

\begin{tabular}{|c|c|c|c|c|c|c|}
\hline \multirow{2}{*}{$\begin{array}{c}\text { Natural } \\
\text { Fibre }\end{array}$} & \multirow[t]{2}{*}{ Matrix } & \multicolumn{3}{|c|}{$\mathrm{NaOH}$ treatment parameters } & \multirow[t]{2}{*}{ Effect/Comment } & \multirow{2}{*}{ Ref. } \\
\hline & & Conc. \% & Temp $\left({ }^{0} \mathrm{C}\right)$ & Duration & & \\
\hline $\begin{array}{l}\text { Pineapple, } \\
\text { Sisal }\end{array}$ & Polyester & 5 and 10 & 30 & $1 \mathrm{hr}$ & $\begin{array}{l}\text { At } 10 \% \quad \mathrm{NaOH}, \text { excess } \\
\text { delignification occurred. Thus } \\
\text { fibre became weaker }\end{array}$ & $\begin{array}{c}\text { Mishra et al., } \\
\text { (2003) [39] }\end{array}$ \\
\hline Sisal & Polyester & $\begin{array}{l}0.25,0.5, \\
1.0, \quad 2.0, \\
5.0 \text { and } 10 \\
\% \text { W/W }\end{array}$ & $\begin{array}{l}\text { Room } \\
\text { temp. }\end{array}$ & $1 \mathrm{hr}$ & $\begin{array}{l}\mathrm{NaOH} \text { treatment decrease fibre } \\
\text { density, } 10 \% \text { treatment results } \\
\text { a rougher surface than } \\
\text { untreated }\end{array}$ & $\begin{array}{c}\text { Sydenstricker } \\
\text { et al., (2003) } \\
{[87]}\end{array}$ \\
\hline $\begin{array}{l}\text { Hemp and } \\
\text { Kenaf }\end{array}$ & Polyester & 6 & $19 \pm 2$ & $40 \mathrm{hrs}$ & $\begin{array}{l}\text { Cell wall densification } \\
\text { identification from small } \\
\text { positive change in fibre density } \\
\text { observation }\end{array}$ & $\begin{array}{c}\text { Aziz and } \\
\text { Ansell } \\
(2004)[88]\end{array}$ \\
\hline Curaua & $\begin{array}{l}\text { Biodegradable } \\
\text { resin }\end{array}$ & $5,10,15 w t$ & $\begin{array}{l}\text { Room } \\
\text { temp }\end{array}$ & $\begin{array}{c}\text { 1hr and } \\
2 \mathrm{hr}\end{array}$ & $\begin{array}{l}\text { Decrease of fibre diameter, } \\
\text { weight, density, and tensile } \\
\text { strenght }\end{array}$ & $\begin{array}{l}\text { Gomes, et } \\
\text { al., (2004) } \\
{[89]}\end{array}$ \\
\hline Henequen & HDPE & $2 \% \mathrm{w} / \mathrm{v}$ & 25 & $1 \mathrm{hr}$ & $\begin{array}{l}\text { Surface modification increase } \\
\text { the area of contact and further } \\
\text { expose the cellulose } \\
\text { microfibril. Thus improve fibre } \\
\text { wetting and impregnation }\end{array}$ & $\begin{array}{l}\text { Herrera- } \\
\text { Franco and } \\
\text { Valadez- } \\
\text { Gonzalez } \\
(2005)[90]\end{array}$ \\
\hline Kenaf & HDPE & 3,6, and 9 & $\begin{array}{l}\text { Room } \\
\text { temp and } \\
900 \mathrm{C} \text { for } \\
6 \%\end{array}$ & $3 \mathrm{hrs}$ & $\begin{array}{l}3 \% \mathrm{NaOH} \text { was ineffective to } \\
\text { remove impurities on fibre } \\
\text { surface, } 9 \% \text { show cleanest fibre } \\
\text { surface }\end{array}$ & $\begin{array}{l}\text { Edeerozey, et } \\
\text { al., (2007) } \\
{[91]}\end{array}$ \\
\hline Pineapple & HDPE & $2 \% \mathrm{w} / \mathrm{v}$ & 95 & $2 \mathrm{hrs}$ & $\begin{array}{l}\text { Decrease in tensile strength and } \\
\text { modulus were probably due to } \\
\text { decrease in degree of } \\
\text { crystallinity }\end{array}$ & $\begin{array}{l}\text { Munawar, et } \\
\text { al., (2008) } \\
{[118]}\end{array}$ \\
\hline $\begin{array}{l}\text { Kenaf, } \\
\text { Flax, } \\
\text { Hemp }\end{array}$ & Epoxy & 5 & $\begin{array}{l}\text { Room } \\
\text { temp }\end{array}$ & $1 \mathrm{hr}$ & $\begin{array}{l}\mathrm{NaOH} \text { treated kenaf and hemp } \\
\text { composites absorb more water } \\
\text { than silane only or alkali and } \\
\text { silane treated samples }\end{array}$ & $\begin{array}{l}\text { Sgriccia, et } \\
\text { al., }(2008) \\
{[75]}\end{array}$ \\
\hline $\begin{array}{l}\text { Sisal and } \\
\text { oil palm }\end{array}$ & Natural rubber & $\begin{array}{c}0.5,1,2, \\
\text { and } 4\end{array}$ & Ambient & $1 \mathrm{hr}$ & 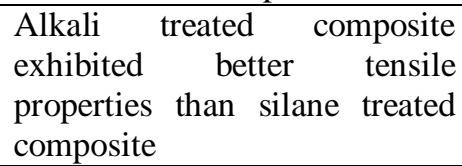 & $\begin{array}{l}\text { John, et al., } \\
(2008) \text { [29] }\end{array}$ \\
\hline Coir & Polypropylene & $\begin{array}{l}2,4,6,8, \\
\text { and } 10\end{array}$ & $\begin{array}{l}\text { Room } \\
\text { temp }\end{array}$ & 4 weeks & $\begin{array}{l}\text { Denser } \mathrm{NaOH} \\
\text { provided more } \mathrm{Na}^{+} \text {and } \mathrm{OH}^{-} \\
\text {ions to react with the } \\
\text { substances on the fibre }\end{array}$ & $\begin{array}{c}\mathrm{Gu},(2009) \\
{[92]}\end{array}$ \\
\hline Ramie & PLA & $5 \% \mathrm{w} / \mathrm{v}$ & $\begin{array}{l}\text { Room } \\
\text { temp }\end{array}$ & $3 \mathrm{hrs}$ & $\begin{array}{lrr}\text { Alkali treated } & \text { composite } \\
\text { exhibited } & \text { better } & \text { tensile } \\
\text { properties than silane } & \text { treated } \\
\text { samples } & & \\
\end{array}$ & $\begin{array}{l}\text { Yu, et al., } \\
(2010)[93]\end{array}$ \\
\hline Hemp & PLA & 5 & Ambient & $30 \mathrm{~min}$ & $\begin{array}{l}\text { Show higher tensile strength } \\
(75.5 \mathrm{MPa}) \text { and modulus } \\
(8.2 \mathrm{GPa})\end{array}$ & $\begin{array}{l}\text { Sawpan, et } \\
\text { al., (2011) } \\
{[94]}\end{array}$ \\
\hline
\end{tabular}

\section{Acetylation Treatment}

Acetylation is a chemical treatment process for surface modification of natural fibres using an anhydrous reagent known as 'Acetic Anhydride'. An<smiles>CC(=O)OC(=O)CCC(=O)OC(C)=O</smiles>

acid anhydride is a compound that is related to an acid by loss of water. Acetic anhydride can be prepared by dehydration of acetic acid at $800^{\circ} \mathrm{C}$.

Alternatively, the reaction between the acid chloride and a salt of acetic acid (e.g. sodium acetate) yields acetic anhydride and a salt [95]. 


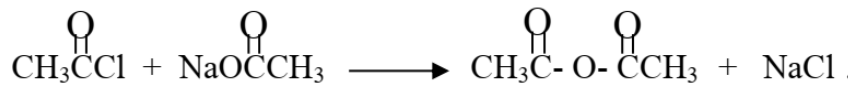

Acetylation describes a reaction introducing an acetyl functional group $\left(\mathrm{CH}_{3} \mathrm{COO}^{-}\right)$into an organic compound. Acetylation of natural fibres is a wellknown esterification method causing plasticization of cellulosic fibres. The reaction involves the generation of acetic acid $\left(\mathrm{CH}_{3} \mathrm{COOH}\right)$ as by-product which must be removed from the lignocellulosic material before the

Fibre $+\mathrm{OH}+\underset{\mathrm{CH}}{\stackrel{\mathrm{C}}{\mathrm{C}}-\mathrm{O}-\mathrm{C}_{\mathrm{C}}} \longrightarrow$ Fibre $-\mathrm{OCOCH}_{3}+\mathrm{CH}_{3} \mathrm{COOH}$

Acetylation is the second fibre surface modification practice this research will engage in the development of its fibre materials, hence we shall further review its applications and findings in literature. Moreover, acetylation can reduce the hygroscopic nature of natural fibres and increase the dimensional ability of composites. It was used in surface treatment of fibres for use in fibre reinforced composites by researchers like Paul, Joseph, and Thomas [97]; Rong, Zhang, Liu, Yang, and Zeng [98]; Hill et al., [96]; Sreekala, and Thomas [99] etc.

Mishra et al., [39] reported an improvement in fibre-matrix adhesion for an alkali treated sisal fibre soaked in glacial acetic acid and later in acetic anhydride containing one drop of $\mathrm{H}_{2} \mathrm{SO}_{4}$ for 5 mins. Nair, Thomas, and Groeninckx [100] reported that the treated surface of sisal fibre became very rough and had a number of voids that provided better mechanical interlocking with polystyrene (PS) matrix after being treated with acetic anhydride. They also found that the thermal stability of the treated composites was higher than that of untreated composites because of improved fibre-matrix interactions in treated fibre composites. Mokaloba and Batane [82] reported increases in interfacial adhesion shear strength by $173 \%$ and $435 \%$ in mercerized and acetylated composites respectively.

Bledzki and Gassan [1] in their work reported a reduction of about $50 \%$ of moisture uptake for acetylated jute fibres and up to $65 \%$ for acetylated pine fibres. Seena, Koshy, and Thomas [101] investigated the effect of acetylation in banana fibre reinforced phenol formaldehyde composites and reported that the tensile strength, tensile modulus and impact strength were found to have been improved compared to untreated banana fibre composites. Zefeiropoulos, Williams, Baillie, Matthews [102], investigated acetylation of flax, hemp, and wood fibres, their findings are that a removal of non-crystalline constituents of the fibres, altered the characteristics of the surface topography, changed the fibre surface free energy and improved the stress transfer efficiency at the interface. fibre is used. Chemical modification with acetic anhydride substitutes the polymer hydroxyl groups of the cell wall with acetyl groups, modifying the properties of these polymers so that they become hydrophobic [96]. The reaction of acetic anhydride with fibre is shown as;
Liu, Wolcott, Gardner, and Rials [103] studied the effect of acetylation in natural fibres such as cotton, wood, and rayon with polystyrene as matrix, where they showed that by using the micro-debonding test, that acetylated fibres had increased interfacial shear strength, and also increased the surface free energy of the fibres. Bledzki, Mamun, Lucka-Gabor, and Gutowski [104] investigated the effects of acetylation on properties of flax fibre and its polypropylene composites, as they found that tensile and flexural strengths of the composites increased with increasing degree of acetylation up to $18 \%$ and then decreased at higher concentration. They also found that impact strength decreased with increasing degree of acetylation, but with the addition of maleated polypropylene (coupling agent) the tensile and flexural strengths were found to increase in between 20 to $35 \%$ depending on degree of acetylation. The effect of chemical treatment on water absorption of Areca fibre was investigated by Dhanalakshmi, Ramadevi, Srinivasa, and Basavaraju [105], the results indicate that the acetylation of areca fibres drastically reduced the water absorption, whereas alkali treatment of the same fibre improves the water absorption.

\section{Silane Treatment $\left(\mathrm{S}_{\mathrm{i}} \mathrm{H}_{4}\right)$}

Silane are good example of cross-linking in the interface region offering a perfect bonding silanes have four main functions [106].

- Cross linking: Once attached to a polymer backbone, silanes can link polymer molecules together via the formation of siloxane bonds, creating a three-dimensional network. This 'cross linking' is activated by ambient moisture and can take place at ambient temperature. Silanes can provide improved thermal stability, creep resistance, hardness and chemical resistance to coatings adhesives and sealants.

- Adhesion Promotion: Silanes can provide improved substrate adhesion in adhesives, sealants and coatings, especially under hot and humid conditions. Silanes are commonly used to improve adhesion to glass, metals and natural fibres, but they can also be beneficial 
with difficult substrates like polyamide, SMC, acrylics, PVC and others.

- Coupling: Silanes can couple inorganic pigments and fillers to organic resins and viceversa. Coupling typically improves the moisture and chemical resistance of the coating or adhesives.

- Dispersion: Silanes can aid in the dispersion of inorganic /organic pigments and fillers in coating, sealants and resins. This can lead to lower viscosity in the formulated product and can improve the hiding power of a coating.

The underlying chemistry of silane treatment is that organo-functional silanes are bi-functional molecules in that they usually have two types of reactivity built into their structures; organic and inorganic (Fig-4). Hydrolysis, condensation and bond formation are the various stages undergone during the treatment process of fibres. During the hydrolysis process, in the presence of moisture and hydrolysable alkoxy group, silanol were formed. While one end of silanol reacts with the cellulose hydroxyl group during consideration process, the other end of silanol reacts with matrix functional group to form a covalent bond [107]. This reaction enhances hydrocarbon chain which prevents swelling of the fibre by creating a cross- linked network because of covalent bonding between the matrix and the fibre [108].

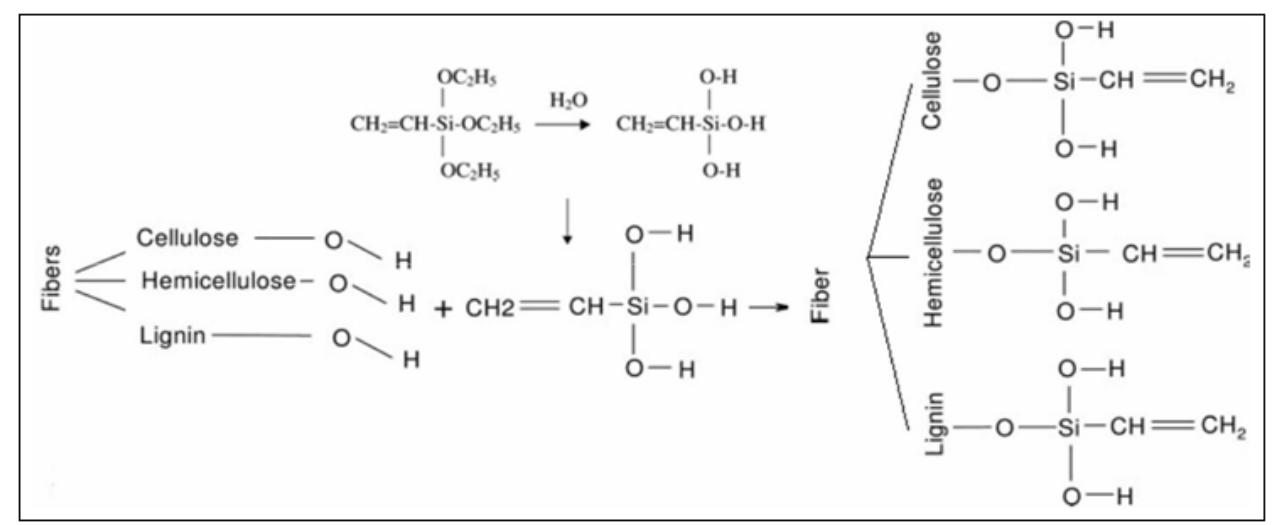

Fig-4: Silanes Interaction with Cellulosic Fibres [25]

\section{Stearic Acid Treatment}

Stearic acid $\left(\mathrm{CH}_{3}\left(\mathrm{CH}_{2}\right) 16 \mathrm{COOH}\right)$ in ethyl alcohol solution is used to modify fibre surfaces. The carboxyl group of stearic acid reacts with the hydrophilic hydroxyl groups of the fibre and improve water resistant properties [109]. Apart from removing the amorphous constituents (Pectin, wax oil etc.) from the removing the amorphous constituent (facilitates fibre dispersion into the matrix to create better boarding at the interface and provides improved properties of the formed composite Torres and Ubillas [110] used 30\% stearic acid treated sisal fibre reinforced polyethylene composites. Zafeiropoulos, Dijon and Baillie [111] put forward that treated flax fibres were more crystalline than the untreated one and stearation decrease the fibre surface free energy. Joseph, Thomas, Pillar, Parsad, Groeminckx and Sarkissova [112], observed that higher tensile strength and modulus properties were improved when sisal fibre was treated with stearic acid in ethyl alcohol solution. Equation (5) shows that reaction between fibre and sicaric acid.

$$
\text { Fibre }-\mathrm{OH}+\mathrm{CH}_{3}\left(\mathrm{CH}_{2}\right) 16 \mathrm{COOH} \longrightarrow \mathrm{CH}_{3}\left(\mathrm{CH}_{2}\right) 16 \mathrm{COO}-\mathrm{O}-\text { Fibre }+\mathrm{H}_{2} \mathrm{O}
$$

\section{Benzoylation Treatment}

In benzoylation treatment, benzoyl chloride is used to decrease hydrophilic nature of the fibre and improves inter-facial adhesion, thereby increasing strength of the composite. It also enhances thermal stability of the fibre [104]. During benzoylaton treatment alkali pre-treatment is used. At this stage, extractable materials such as lignin, waxes and oil covering materials are removed and more reactive hydroxyl $(\mathrm{OH})$ groups are exposed on the fibre surface, then treated with benzoyl chloride. The $\mathrm{OH}$ groups of the fibre are further replaced by benzoyl group and it attached on the cellulose backbone. This results in more hydrophobic nature of the fibre and improve adhesion with matrix. Possible reaction between cellulosic $-\mathrm{OH}$ and benzoly-chloride is given by equation (6) and (7) [113].

Fibre $-\mathrm{OH}+\mathrm{NaOH} \longrightarrow$ Fibre $-\mathrm{O}^{-} \mathrm{Na}^{+}+\mathrm{H}_{2} \mathrm{O}$ 
Fibre $-\mathrm{O}^{-} \mathrm{Na}^{+}+\mathrm{ClC}-\leadsto$ Fiber $-\mathrm{O}-\mathrm{C}-\longrightarrow+\mathrm{NaCl}$

\section{Fatty acid derivative (Oleoyl chloride) treatment}

Fatty acid derivative are used as a coupling agent to modify fibre surface to improve well ability and interfacial adhesion characteristics. Oleoyl chloride is a fatty acid derivate which reacts with the hydroxyl group (esterification) and grafted on the cellulose backbone of the fibre. During esterification, the molecules are penetrating inside the cellulose structure and reacts with hydroxyl groups of the fibre and the matrix. Additionally, hydrophilic hydroxyl groups present on the external surface are removed by this treatment and make the fibre more hydrophobic. This improves the wetting and adhesion of fibre surface into the matrix and provides improved composite properties. Modification of jute fibre with dichloromethane and pyridine solvent under a dry nitrogen atmosphere results in more hydrophobic characteristics and increases composite properties [114].

\section{Triazine Treatment}

Triazine treatment is used for surface modification of natural fibres. A triazine $\left(\mathrm{C}_{3} \mathrm{H}_{3} \mathrm{~N}_{3}\right)$ derivative e.g. $\mathrm{C}_{3} \mathrm{H}_{3} \mathrm{~N}_{3} \mathrm{Cl}_{3}$ has multifunctional groups in its structure. The reactive chlorines that are present in the heterocyclic ring reacts with the hydroxyl groups of the fibre by esterification and provide linkage between the cellulose phase and coupling agent. The carboncarbon double bonds from covalent bonds with the matrix by grafting. It also provides a secondary reaction with the hydrophilic hydroxyl groups of cellulose and lignin that provides better moisture resistance properties (Fig-5).

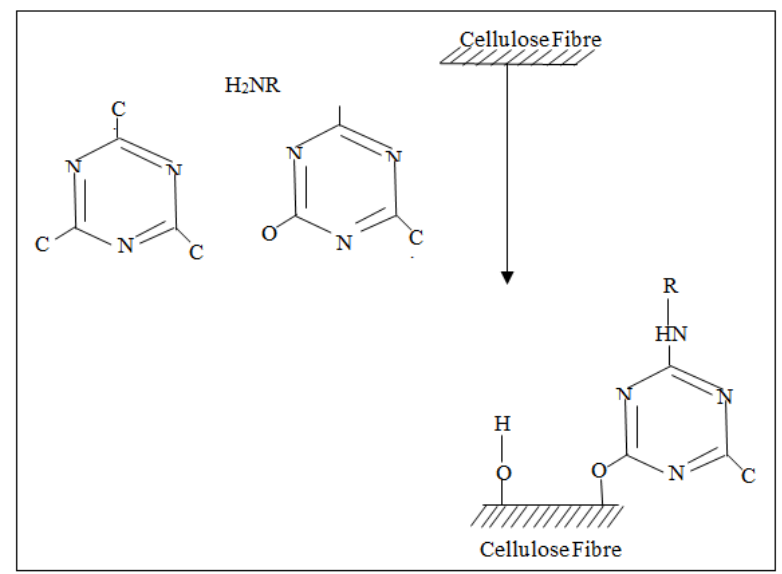

Fig-5: Modification of Cellulose Fibres with Trizine Derivatives

This modification provides cross linking between the cellulose (through hydrogen bond) and matrix. This results to strong adhesion at the interface and improves composite properties [115]. Bismarck, Misra, and Lampke [116] used trichloro-s-triazine base different coupling agents to treat cellulose resin.
Improved fibre matrix adhesion and higher moisture resistance properties were reported for the treated fibre composites.

\section{CONCLUSION}

Natural fibres have shown to be the engineering material of the century in the areas of composites and material sciences. This is made emphatic going by its growing applications in various engineering endeavour. They have unequivocally gain the interest of scientists and researchers alike which made this review paper a scratch on the body of literatures with respect to natural composites materials. Nevertheless, these materials of nature have their back drops which is their high affinity for water leading to poor wettability properties with their majorly polymer based matrix for composite materials formation. The process of improving the natural fibre Tribological property involves surface modification or treatment which has been reviewed in this paper. Among all the different ways or modes of treating natural fibres, the methods of alkaline and acetic anhydride chemical treatments showed to be the most applied methods of surface modification of natural fibres for improved surface interaction properties.

\section{REFERENCES}

1. Bledzki, A. K., \& Gassan, J. (1999). Composites reinforced with cellulose based fibres. Progress in polymer science, 24(2), 221-274.

2. Trigui, A., Karkri, M., Pena, L., Boudaya, C., Candau, Y., Bouffi, S., \& Vilaseca, F. (2013). Thermal and mechanical properties of maize fibres-high density polyethylene biocomposites. Journal of Composite Materials, 47(11), 1387-1397.

3. Al-Kaabi, K., Al-Khanbashi, A., \& Hammami, A. (2005). Date palm fibers as polymeric matrix reinforcement: $\mathrm{DPF} /$ polyester composite properties. polymer composites, 26(5), 604-613.

4. Kelly, A. (2006). Composite Materials after Seventy Years. Journal of Material Science, 41, 905-912.

5. Venkateshappa, S. C., Jayadevappa, S. Y., \& Puttiah, P. K. W. (2012). Mechanical Behaviour of Areca Fibre Reinforced Epoxy Composites. Advances in Polymer Technology, 31(4), 319-330.

6. Barbero, E. J. (1999). Introduction to Composite Materials Design, Department of Mechanical and Aerospace Engineering West Virginia University, U.S.A.

7. Manjunath, B. H., \& Rao, K. P. (2013). Influence Of Fiber/Filler Particles Reinforcement On Epoxy Composites. Composites, 3(3):1147-1151.

8. Saravana, B. D., \& Mohan, K. G. C. (2013). Thermal Properties of Maize Fibre Reinforced 
Unsaturated Polyester Resin Composites. In: Proceedings of the World Congress on Engineering, Vol. III, WCE, July 3-5, London, U.K.

9. Marsh, G. (2013). Composites poised to transform airline economics. Reinforced Plastics, 57(3), 1824.

10. Kim, S. W., Lee, S. H., Kang, J. S., \& Kang, K. H. (2006). Thermal conductivity of thermoplastics reinforced with natural fibers. International journal of thermophysics, 27(6), 1873-1881.

11. Agarwal, R., Saxena, N. S., Sharma, K. B., Thomas, S., \& Pothan, L. A. (2006). Thermal conduction and diffusion through polyester composites. Indian Journal of Pure and Applied Physics, 44, 746-750.

12. Springer, G. S., \&Tsai, S. W. (1967). Thermal Conductivity of Unidirectional Materials. Journal of Composite Science and Technology, 1(2), 166173.

13. Ticoalu, A., Aravinthan, T., \& Cardona, F. (2010). A Review of Current Developments in Natural fibre composites for Structural and Infrastructural Applications. Southern Region Engineering Conference, University of Southern Queensland, Toowoomba, Australia.

14. Rowell, R. M. (2008). Natural Fibres: Types and Properties, in Properties and Performance of National Fibre Composites. K. Pickening, Ed., ed Cambridge: Woodhead Publishing Limited.

15. O'Donnel, A., Dweib, M., \& Woll, R. (2004). Natural Fibre Composites with PHnt-ceil Based Resin. Composites Sciences and Technology, 64, 1135-1145.

16. Herrera-Franco, P., \& Valadez-Gonzalez, A. (2005). A study of the mechanical properties of short natural-fiber reinforced composites. Composites Part B: Engineering, 36(8), 597-608.

17. Zhu, J., Zhu, H., Njuguna, J., \& Abhyankar, H. (2013). Recent development of flax fibres and their reinforced composites based on different polymeric matrices. Materials, 6(11), 5171-5198.

18. Cheung, H. Y., Ho, M. P., Lau, K. T., Cardona, F., \& Hui, D. (2009). Natural fibre-reinforced composites for bioengineering and environmental engineering applications. Composites Part B: Engineering, 40(7), 655-663.

19. Maleque, M. A., Saiful, A., \& Sapuan, S. A. (2005). Effect of Volume fraction of Pseudo Stem Banana Fibre on the Properties of Epoxy Composite. In: Proceedings of the International Conference on Mechanical Engineering, Dhaha, Bangladesh, Dec. 28-30, Pp AM-47.

20. Hautala, M., Pasila, A., \& Pirilä, J. (2004). Use of hemp and flax in composite manufacture: a search for new production methods. Composites Part A: Applied Science and Manufacturing, 35(1), 11-16.

21. Ishak, M. R., Leman, Z., Sapuan, S. M., Salleh, M. Y., \& Misri, S. (2009). The effect of sea water treatment on the impact and flexural strength of sugar palm fibre reinforced epoxy composites. International Journal of Mechanical and Materials Engineering, 4(3), 316-320.

22. Leman, Z., Sapuan, S. M., Saifol, A. M., Naleque, M. A., \& Ahmad, M. M. H. M. (2008). Moisture Absorption Behaviour of Sugar Palm fibre Reinforced Epoxy Composites. Material and Design, Elsevier Science, UK, 29(8), 1666-1670.

23. Leman, Z., Sapuan, S. M., Azwan, M., Ahmad, M. M. H. M., \& Makque, M. A. (2008). The Effect of Environmental Treatments on Fibre Surface Properties and Tensile Strength of Sugar Palm Fibre Reinforced Epoxy Composites. Polymer Plastics Technology and Engineering, Taylor and Frances, UK, 47(6), 606-612.

24. Joseph, K., Thomas, S., \& Pavithran, C. (1996). Effect of chemical treatment on the tensile properties of short sisal fibre-reinforced polyethylene composites. Polymer, 37(23), 51395149.

25. Shehu, U., Audu, H. I., Nwamara, M. A., AdeAjayi, A. I. Shuittu, U. M., \& Isa, M. T. (2014). Natural Fibre as Reinforcement for Polymers. A Review. South Pacific Journal of Technology and Science, 2(1), 238-251.

26. Chawla, K. K. (1987). Composite Materials, Science and Engineering, $3^{\text {rd }}$ edition, New York: Springer-Verlag.

27. Mohanty, A. K., Misra, M. A., \& Hinrichsen, G. I. (2000). Biofibres, biodegradable polymers and biocomposites: An overview. Macromolecular materials and Engineering, 276(1), 1-24.

28. Ochi, S. (2008). Mechanical properties of kenaf fibers and kenaf/PLA composites. Mechanics of materials, 40(4-5), 446-452.

29. John, M. J., \& Thomas, S. (2008). Bofibres and Bio-composites. Carbohydrate Polymers, 71(3), 342-364.

30. Subramani, T., \& Vishnupriya, S. (2014). Finite Element of a Natural Fibre (Mazie) Composite Beam. International Journal of Modern Engineering Research, 4(6), 1-7.

31. Gunti, R., \& Atluri, P. A. V. (2013). Study on Effect of Chemical Treatments and Concentration of Jute on Tensile Properties of Long and Continuous Twisted Jute/Polypropylene Composites. Advanced Materials Manufacturing and Characterization, 3(1), 395-398.

32. [33] Bongade, U.S., and Shinde, V.D. (2014). Review on Natural Fibre Reinforcement Polymer Composite. International Journal of Engineering Science and Innovative Technology, 3(2), 431-436.

33. Alamri, H., \& Low, I. M. (2012). Effect of Waster Absorption in the Mechanical Properties of n-SiC Filled Recycled Cellulose Fibre Reinforced Epoxy Eco-nano Composites. Polymer Testing, 6(1), 810818. 
34. Amar, K. M., Mangusri, M., \& Lawrence, T. D. (2005). Natural Fibres, Biopolymers, and Biocomposites. CRC Press Tailor and Francis.

35. Hussain, A. I., Abdel, K., \& Ibrahim, A. (2010). Effect of Modified Linen Fibre Waste on PhysioMechanicial Properties of Polar and Non-Polar Rubber. Journal of Natural Science, 8(8), 82-89.

36. Mwaikambo, L.Y., \& Ansell, M. P. (2002). Chemical Modification of Hemp, Sisal, Jute and Kapok Fibes by Alkalization. Journal of Applied Polymer Science, 33(84), 2222-2234.

37. Abdelmonleh, M., Bouti, S., Belgacem, M.N., Duarte, A. P., Salah, A. B., \& Gardini, A. (2004). Modification of Cellulosic Fibres with Functionalized Silanes: Development of Surface Properties. International Journal of Adhesive, 24(1), 43-54.

38. Maya, J., \& Radesh, A. (2008). Recent Development in Chemical Modification and Characterization of Natural Fibre Reinforced Composites. Journal of Polymer Composites, 14(11), 188-209.

39. Mishra, S., Mohanty, A. K., Drzal, L. T., Misra, M. Parija, S., Nayak, S. K., \& Tipathy, S. S. (2003). Studies on Mechanical Performance of Biofiber/ Glass Reinforced Polyester Hybrid Composites. Composite Science and Technology, 63(10), 1377-1385.

40. Khoshnava, S. M., Rostami, R., Ismai, M., \& Valipour, A. (2014). The using of Fungi Treatment as Green and Enviormnetally Process for Surface Modification of Natural Fibres. Applied Mechanics and Materials Trans Tech Publications, Switzerland, 554, 116-122.

41. Netravali, A. N. (2007). Fibre/Resin Interface Modification in Green Composites. In; BhattaCharyya SFaD (ed). Handbook of Engineering Biopolymers Homopolymers Blends and Composites, Munich; Hanser, 857-868.

42. Jafari, M. A., Nikkhah, A., Sadeghi, A. A., \& Chamani, M. (2007). The effect of Pleurotus spp. fungi on chemical composition and in vitro digestibility of rice straw. Pak J Biol Sci, 10(15), 2460-2464.

43. Kabir, M. M., Wang, H., Lau, K. T., \& Cardona, F. (2012). Chemical treatments on plant-based natural fibre reinforced polymer composites: An overview. Composites Part B: Engineering, 43(7), 2883-2892.

44. Baldrian, P., \& Valášková, V. (2008). Degradation of cellulose by basidiomycetous fungi. FEMS microbiology reviews, 32(3), 501-521.

45. Li, Y., Pickering, K. L., \& Farrell, R. L. (2009). Analysis of green hemp fibre reinforced composites using bag retting and white rot fungal treatments. Industrial crops and products, 29(2-3), 420-426.

46. Alexopoulas, C. J., Mims, C. W., \& Blackwell, M. (1996). Introductory mycology, $4^{\text {th }}$ edition, (pp.888) New York: John Wiley and Sons, Inc.
47. Martin, H. (2002). Review: lignin conversion by manganese peroxidase (MnP). Enz Microb Technol, 30, 454-466.

48. Forde, K., Lois, J., Dinus, R. J., Nakolm, E. W., Rudie, A. W., Farrell, R. L., \& Brush, T. S. (1995). Improving Softwood Mechanical Pulp Properties with Ophiostoma Piliferum. Tappi Journal, 80(3), 135-139.

49. Tamerler, C. B., Martinez, A. T., \& Keshavarz, T. (2001). Production of Lipolytic Enzymes in Batch Cultures of Ophiostoma Piceae. Journal of Chemical Technology and Biotechnology, 10, 252258.

50. Call, H. P., \& Mücke, I. (1997). History, overview and applications of mediated lignolytic systems, especially laccase-mediator-systems (Lignozym ${ }^{\circledR}$ process). Journal of Biotechnology, 53(2-3), 163202.

51. Breen, A., \& Singleton, F. L. (1999). Fungi in lignocellulose breakdown and biopulping. Current Opinion in Biotechnology, 10(3), 252-258.

52. Gutiérrez, A., del Río, J. C., Martínez, M. J., \& Martínez, A. T. (2001). The biotechnological control of pitch in paper pulp manufacturing. TRENDS in Biotechnology, 19(9), 340-348.

53. Gulati, D., \& Sain, M. (2006). Fungalmodification of natural fibers: a novel method of treating natural fibers for composite reinforcement. Journal of Polymers and the Environment, 14(4), 347-352.

54. El-Saled, H., Basta, A. H., \& Gobran, R. H. (2004). Research Progress in Friendly Environment Technology for the Production of Cellulose and its Application. Polymer PlasticTechnology and Engineering, 43(3), 797820.

55. Pommet, M., Juntaro, J., Heng, J. Y. Y., Mantalaris, A., Lee, A. F., Wilson, K., Kalinka, G., Shaffer, M. S. P., \& Bismarck, A. (2008). Surface Modificaiton of Natural Fibres Using Bacteria: Depositing Bactria Cellulose onto Natural Fibre to create Hierarihical Fibre Reinforced Nanocomposites. Biomaceomoleules, American Chemical Society, 9, 1643-1651.

56. Guhados, G., Wan, W., \& Hutter, J. L. (2005). Measurement of the Elastic Modulus of Single Bacteral Cellulose Fibres Using Atomic Force Microscospy. Langmuir, ACS Publications, 21(4), 6642-6646.

57. Saechtling, H. (1987). International Plastics Handbook. Munich, Germany: Hanser Gardner Publications.

58. Gassan, J., \& Gutowski, V. S. (2000). Effects of corona discharge and UV treatment on the properties of jute-fibre epoxy composites. Composites Science and Technology, 60(15), 2857-2863.

59. Pizzi, A., Kueny, R., Lecoanet, F., Massetau, B., Carpentier, D., Krebs, A., ... \& Ragoubi, M. 
(2009). High resin content natural matrix-natural fibre biocomposites. Industrial Crops and Products, 30(2), 235-240.

60. Gassan, J., \& Gutowski, V. S. (2000). Effects of corona discharge and UV treatment on the properties of jute-fibre epoxy composites. Composites Science and Technology, 60(15), 2857-2863.

61. Martin, A. R., Manolache, S., Mattoso, L. H. C., Rowell, R. M. \& Dense, F. (2000). Plasma Modification of Sisal and High Density Polyethylene Composites: Effect on Mechanical Properties. Natural Polymers and Composite Proceedings, 431-436.

62. Marais, S., Gouanvé, F., Bonnesoeur, A., Grenet, J., Poncin-Epaillard, F., Morvan, C., \& Métayer, M. (2005). Unsaturated polyester composites reinforced with flax fibers: effect of cold plasma and autoclave treatments on mechanical and permeation properties. Composites Part A: Applied Science and Manufacturing, 36(7), 975986.

63. Seki, Y., Sever, K., Sarikanat, M., Gulec, H. A., \& Tavman, I.H. (2009). The Influence of Oxygen Plasma Treatment of Jute Fibres on Mechanical Properties of Jute Reinforced Thermoplastic Composites. $5^{\text {th }}$ International Advanced Technologies Symposium (IATS'90), Karabuk, Turkey.

64. Sinha, E., \& Panigrahi, S. (2009). Effect of plasma treatment on structure, wettability of jute fiber and flexural strength of its composite. Journal of composite materials, 43(17), 1791-1802.

65. Xu, X., Wang, Y., Zhang, X., Jing, G., Yu, D., \& Wang, S. (2006). Effects on Surface Properties of Natural Bamboo FibresTreated with Atmospheric Pressure Argon Plasma. Surface and Interface Analysis, 38(8), 1211-1217.

66. Roth, R. (2001). Industrial Plasma Engineering. Bristol: Institute of Physics Publishing.

67. Taj, S., Munawar, M. A., \& Khan, S. (2007). Review: Natural Fibre Reinforced Ploymer Composites. The Proceedings of the Pakistan Academy of Science, 44(2), 129-144.

68. Kalia, S., Kaith, B. S., \& Kaur, I. (2009). Pretreatments of natural fibers and their application as reinforcing material in polymer composites-A review. Polymer Engineering \& Science, 49(7), 1253-1272.

69. Kaushik, K.V., Kumar, A., Vashistha, S., \& Kalia, S. (2010). Effect of Chemical Treatment on the Morphology, Structure and Properties of Sisal Fibres. International Conference on Advances in Polymer Technology, India, 248-252.

70. Liu, X. Y., \& Dai, G. C. (2007). Surface Modification and Micromechanical Properties of Jute Fibre Mat reinforced Polypropylene Composites. eXpress Polymer Letters, 1(5), 299307.
71. Fengel, D., \& Wegener, G. (1983). Wood: Chemistry, Ultrastructure, Reactions, De Gruyter, Berkom, 483.

72. Kumar, R., Obrai, S., \& Sharma, A. (2011). Chemical Modification of Natural Fibre for Composite Material. Pelagin Research Library, 2(4), 219-228.

73. Jacob, M., Thomas, S., \& Varughese, K. T. (2004). Mechanical Properties of Sisal/Oil Palm Hybrid Fibre Reinforced Natural Rubber Composites. Composite Science and Technology, 64, 955-965.

74. Le Troedec, M., Sedan, D., Peyratout, C., Bonnet, J. P., Smith, A., Guinebretiere, R., ... \& Krausz, P. (2008). Influence of various chemical treatments on the composition and structure of hemp fibres. Composites Part A: Applied Science and Manufacturing, 39(3), 514-522.

75. Sgriccia, N., Hawley, M. C., \& Misra, M. (2008). Characterization of natural fiber surfaces and natural fiber composites. Composites Part A: Applied Science and Manufacturing, 39(10), 1632 1637.

76. John, M. J., \& Anandjiwala, R. D. (2008). Recent developments in chemical modification and characterization of natural fiber-reinforced composites. Polymer composites, 29(2), 187-207.

77. Kabir, M. M., Wang, H., Aravinthan, T., Cardona, F., \& Lau, K. T. (2011, April). Effects of natural fibre surface on composite properties: A review. In Proceedings of the 1st international postgraduate conference on engineering, designing and developing the built environment for sustainable wellbeing (eddBE2011) (pp. 9499). Queensland University of Technology.

78. Oladele, I. O., Omotoyinbo, J. A., \& Adewara, J. O. T. (2010). Investigating the effect of chemical treatment on the constituents and tensile properties of sisal fibre. Journal of Minerals and Materials Characterization and Engineering, 9(06), 569582.

79. Mwaikambo, L. Y., \& Ansell, M. P. (1999). Effect of Chemical Treatment on the Properties of Hemp, Sisal, Jute, and Kapok Fibres for Composites Reinforcement. $2^{\text {nd }}$ International Wood and Natural Fibre Composites Symposium, Kassel, Germany, 1-6.

80. Pothan, L. A., George, J., \& Thomas, S. (2002). Effect of fiber surface treatments on the fibermatrix interaction in banana fiber reinforced polyester composites. Composite Interfaces, 9(4), 335-353.

81. Punyamurthy, R., Sampathkumar, D., Srinivasa, C. V., \& Bennehalli, B. (2012). Effect of alkali treatment on water absorption of single cellulosic abaca fiber. BioResources, 7(3), 3515-3524.

82. Mokaloba, N., \& Batane, R. (2014). The effects of mercerization and acetylation treatments on the properties of sisal fiber and its interfacial adhesion characteristics on polypropylene. International 
Journal of Engineering, Science and Technology, 6(4), 83-97.

83. Favaro, S. L., Ganzerli, T. A., de Carvalho Neto, A. G. V., Da Silva, O. R. R. F., \& Radovanovic, E. (2010). Chemical, morphological and mechanical analysis of sisal fiber-reinforced recycled highdensity polyethylene composites. Express Polymer Letters, 4(8), 465-473.

84. Ouajai, S., Hodzic, A., \& Shanks, R. A. (2004). Morphological and grafting modification of natural cellulose fibers. Journal of Applied Polymer Science, 94(6), 2456-2465.

85. Jayaramudu, J., Guduri, B. R., \& Rajulu, A. V. (2009). Characterization of natural fabric Sterculia urens. International Journal of Polymer Analysis and Characterization, 14(2), 115-125.

86. Hashim, M. Y., Roslan, M. N., Amin, A. M., Zaidi, A. M. A., \& Arifin, S. (2012). Mercerization Treatment Parameter Effect on Natural Fibre reinforced Polymer Matrix Composite: A Brief Review. International Scholarly and Scientific Research and Innnovation, 6(8), 1378-1384.

87. Sydenstricker, T. H., Mochnaz, S., \& Amico, S. C. (2003). Pull-out and other evaluations in sisalreinforced polyester biocomposites. Polymer testing, 22(4), 375-380.

88. Aziz, S. H., \& Ansell, M. P. (2004). The effect of alkalization and fibre alignment on the mechanical and thermal properties of kenaf and hemp bast fibre composites: Part 1-polyester resin matrix. Composites science and technology, 64(9), 1219-1230.

89. Gomes, A., Goda, K., \& Ohgi, J. (2004). Effects of alkali treatment to reinforcement on tensile properties of curaua fiber green composites. JSME International Journal Series A Solid Mechanics and Material Engineering, 47(4), 541-546.

90. Herrera-Franco, P., \& Valadez-Gonzalez, A. (2005). A study of the mechanical properties of short natural-fiber reinforced composites. Composites Part B: Engineering, 36(8), 597-608.

91. Edeerozey, A. M., Akil, H. M., Azhar, A. B., \& Ariffin, M. Z. (2007). Chemical modification of kenaf fibers. Materials letters, 61(10), 2023-2025.

92. Gu, H. (2009). Tensile behaviours of the coir fibre and related composites after $\mathrm{NaOH}$ treatment. Materials \& Design, 30(9), 3931-3934.

93. Yu, T., Ren, J., Li, S., Yuan, H., \& Li, Y. (2010). Effect of fiber surface-treatments on the properties of poly (lactic acid)/ramie composites. Composites Part A: Applied Science and Manufacturing, 41(4), 499-505.

94. Sawpan, M. A., Pickering, K. L., \& Fernyhough, A. (2011). Improvement of mechanical performance of industrial hemp fibre reinforced polylactide biocomposites. Composites Part A: Applied Science and Manufacturing, 42(3), 310319.
95. Shakhashiri, P. (2008). Chemical of the Week: Acetic Acid and Acetic Anhydride. General Chemistry. www.scifun.org.

96. Hill, C. A., Khalil, H. A., \& Hale, M. D. (1998). A study of the potential of acetylation to improve the properties of plant fibres. Industrial Crops and Products, 8(1), 53-63.

97. Paul, A., Joseph, K., \& Thomas, S. (1997). Effect of surface treatments on the electrical properties of low-density polyethylene composites reinforced with short sisal fibers. Composites Science and Technology, 57(1), 67-79.

98. Rong, H. J., Ong, Y. S., Tan, A. H., \& Zhu, Z. (2008). A fast pruned-extreme learning machine for classification problem. Neurocomputing, 72(13), 359-366.

99. Sreekala, M. S., \& Thomas, S. (2003). Effect of fibre surface modification on water-sorption characteristics of oil palm fibres. Composites Science and Technology, 63(6), 861-869.

100. Nair, K. M., Thomas, S., \& Groeninckx, G. (2001). Thermal and dynamic mechanical analysis of polystyrene composites reinforced with short sisal fibres. Composites Science and Technology, 61(16), 2519-2529.

101. Joseph, S., Koshy, P., \& Thomas, S. (2005). The role of interfacial interactions on the mechanical properties of banana fibre reinforced phenol formaldehyde composites. Composite Interfaces, 12(6), 581-600.

102. Zafeiropoulos, N. E., Williams, D. R., Baillie, C. A., \& Matthews, F. L. (2002). Development and investigation of surface treatments. Composites Part A, 33, 1083-1093.

103. Liu, F. P., Wolcott, M. P., Gardner, D. J., \& Rials, T. G. (1994). Characterization of the interface between cellulosic fibers and a thermoplastic matrix. Composite Interfaces, 2(6), 419-432.

104. Bledzki, A. K., Mamun, A. A., Lucka-Gabor, M., \& Gutowski, V. S. (2008). The effects of acetylation on properties of flax fibre and its polypropylene composites. Express Polymer Letters, 2(6), 413-422.

105. Sampathkumar, D., Punyamurth, R., Venkateshappa, S. C., \& Bennehalli, B. (2012). Effect of chemical treatment on water absorption of areca fiber. Journal of Applied Sciences Research, 8(11), 5298-5305.

106. Momentive. (2011). Silquest Silanes Selector and Handling Guide. Momentive Performance Materials, Albany, New York, U.S.A.

107. Sreekala, M. S., Kumaran, M. G., Joseph, S., Jacob, M., \& Thomas, S. (2000). Oil palm fibre reinforced phenol formaldehyde composites: influence of fibre surface modifications on the mechanical performance. Applied Composite Materials, 7(5-6), 295-329.

108. Gao, S. L., \& Mäder, E. (2006). Jute/polypropylene composites I. Effect of matrix 
modification. Composites Science and Technology, 66(7-8), 952-963.

109. Wang, B., Panigrahi, S., Tabil, L., \& Crerar, W. (2004). Effects of chemical treatments on mechanical and physical properties of flax fiberreinforced rotationally molded composites. In 2004 ASAE Annual Meeting (p. 1). American Society of Agricultural and Biological Engineers.

110. Torres, F. G., \& Cubillas, M. L. (2005). Study of the interfacial properties of natural fibre reinforced polyethylene. Polymer Testing, 24(6), 694-698.

111. Zafeiropoulos, N. E., \& Baillie, C. A. (2007). A study of the effect of surface treatments on the tensile strength of flax fibres: Part II. Application of Weibull statistics. Composites Part A: Applied Science and Manufacturing, 38(2), 629-638.

112. Joseph, P. V., Joseph, K., Thomas, S., Pillai, C. K. S., Prasad, V. S., Groeninckx, G., \& Sarkissova, M. (2003). The thermal and crystallisation studies of short sisal fibre reinforced polypropylene composites. Composites Part A: Applied Science and Manufacturing, 34(3), 253-266.

113. Joseph, S., Oommen, Z., \& Thomas, S. (2006). Environmental durability of banana-fiberreinforced phenol formaldehyde composites. Journal of Applied Polymer Science, 100(3), 2521-2531.

114. Qiu, W., Endo, T., \& Hirotsu, T. (2006). Structure and properties of composites of highly crystalline cellulose with polypropylene: Effects of polypropylene molecular weight. European Polymer Journal, 42(5), 1059-1068.

115. Maleque, M. A., Belal, F. Y., \& Sapuan, S. M. (2007). Mechanical Properties Study of Pseudo Stem Banana Fibre Reinforced Epoxy Composite. Annual Journal Science Engineering, 32(2B), 359364.

116. Bismarck, A., Mishra, S., \& Lampke, T. (2005). Natural Fibres Biopolymers and Biocomposites, CRC Press, Boca Baton, Florida, 37-108.

117. Baranitharan, P., \& Mahesh, G. (2014). Alkali Treated Maize fibres Reinforced with Epoxy Poly Matrix Composites. International Journal of Innovative Science and Modern Engineering, 2(5), 1-7.

118. Munawar, S. S., Umemura, K., Tanaka, F., \& Kawai, S. (2008). Effects of alkali, mild steam, and chitosan treatments on the properties of pineapple, ramie, and sansevieria fiber bundles. Journal of wood science, 54(1), 28-35. 